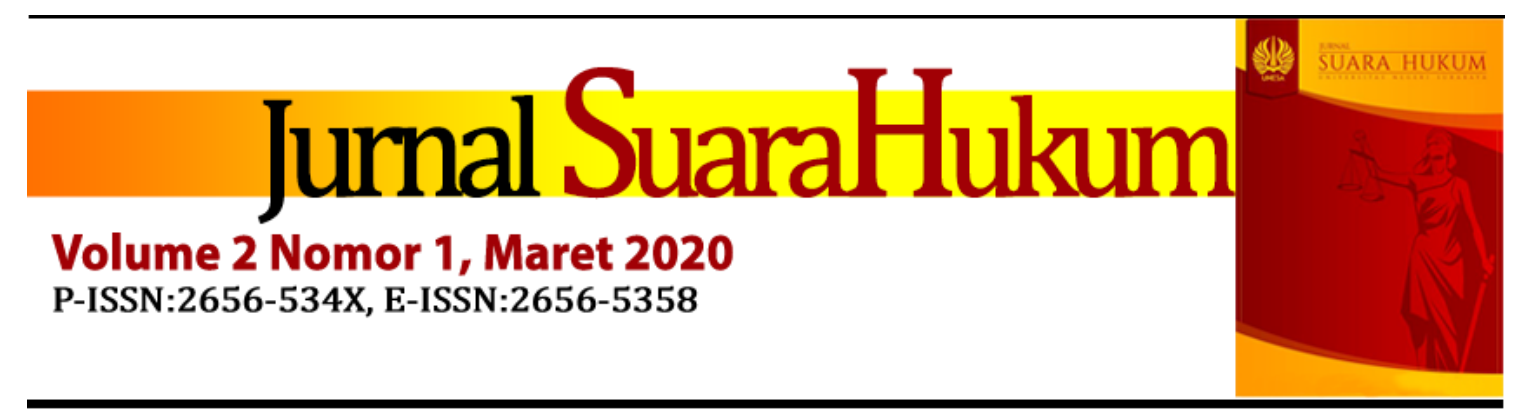

\title{
Kedudukan Legal Opinion sebagai Sumber Hukum
}

\section{Ery Agus Priyono ${ }^{1}$ dan Kornelius Benuf ${ }^{2}$}

${ }^{1}$ Fakultas Hukum, Universitas Diponegoro, Semarang, Indonesia eap_fh_undip@yahoo.com

${ }^{2}$ Fakultas Hukum, Universitas Diponegoro, Semarang, Indonesia korneliusbenuf@gmail.com

\begin{abstract}
Law is a means to achieve the order and welfare of the community. One of the sources of law is doctrine. The doctrine is essentially the opinion of a legal expert on a real legal issue. When discussing legal opinions, the term legal opinion is also known. Doctrine and Legal Opinion are mostly the same, namely the legal opinion of a legal expert on a real legal problem. If we agree that Doctrine and Legal Opinion are the same way in much of the literature that is mentioned as a source of law is the only doctrine, whereas where is legal opinion placed in the formation of a law? This paper will explain the position of Legal opinion as a source of law.
\end{abstract}

Keywords: Doctrine, Legal Opinion, Legal Sources

\section{Pendahuluan}

Semakin berkembangnya zaman dan terus bertambahnya kebutuhan masyarakat di bidang jasa hukum, saat ini tugas seorang pengacara tidak hanya terbatas menjalankan fungsi beracara di muka hakim dan/atau pengadilan. Sebagai seseorang yang berkecimpung di dunia hukum, pengacara akan sering berhubungan dengan banyak orang dalam lingkup pekerjaan maupun di luar pekerjaannya, baik dengan mereka yang mengerti hukum maupun tidak mengerti hukum. Mereka akan menanyakan masalah-masalah dan bagaimana pendapat seorang pengacara.

Pengacara harus dapat menjawab dan menjelaskan dengan penjelasan yang semudah mungkin sehingga dapat dimengerti oleh mereka yang kurang 
mengerti tentang hukum. Terbukti makin maraknya tenaga Konsultan Hukum yang dipakai di berbagai bidang usaha yang salah satu perannya adalah mengemukakan Legal Opinion. Selain itu tradisi hukum yang lebih menunjukan penjelasan putusan terhadap para pengacara yang mungkin tidak mencoba menerjemahkan langsung putusan dengan suatu bahasa yang mudah dimengerti kepada pihak terkait mewajibkan seorang pengacara dapat merumuskan nya dalam bahasa yang mudah dimengerti kepada klien nya. Berdasarkan hal yang disebutkan di atas, maka diperlukannya kemampuan bagi orang hukum untuk memberikan pendapat hukum miliknya terhadap suatu permasalahan.

Legal Opinion merupakan jawaban seorang sarjana hukum, mengenai pertanyaan seorang klien yang sedang menghadapi persoalan hukum. Apabila pendapat hukum seorang sarjana hukum ini dijadikan oleh hakim sebagai tempat menemukan hukum maka pendapat hukum tersebut sudah bisa dikatakan sebagai doktrin. ${ }^{1}$ Doktrin merupakan salah satu sumber hukum. ${ }^{2}$ Artinya ada hubungan antara legal opinion dan doktrin yang merupakan sumber hukum. Satjipto Rahardjo mengatakan proses pembuatan hukum salah satunya yaitu sosio-politis yang artinya gagasan masyarakat yang menginginkan suatu masalah bisa diatur oleh hukum, gagasan tersebut diolah oleh masyarakat sendiri, dikritik, dibicarakan, dipertahankan melalui pertukaran pendapat antar berbagai golongan atau kekuatan dalam masyarakat. ${ }^{3}$ Artinya pendapat hukum merupakan hal terpenting dalam pembuatan hukum, tanpa adanya pendapat hukum maka suatu masalah yang ingin diselesaikan dalam masyarakat tidak akan diketahui cara penyelesaiannya.

Berdasarkan paparan di atas, jelas bahwa Pendapat Hukum (Legal Opinion) merupakan doktrin yang utamanya disajikan dalam rangka kepentingan praktis. Doktrin merupakan salah satu sumber hukum. Jika Legal opinion sama dengan

\footnotetext{
1 Sudikno, Mertokusumo. (2008). Mengenal Hukum Suatu Pengantar. Yogyakarta: Liberty, hlm. 116

2 Ibid, hlm. 85

3 Satjipto, Rahardjo. (2014). Ilmu Hukum. Semarang: Citra Aditya Bakti, hlm. 187
} 
doktrin maka mengenai kedudukan legal opinion sebagai sumber hukum, inilah yang akan dibahas dalam tulisan ini. Sajian singkat ini ingin mengemukakan pokok bahasan yang berkaitan dengan apa yang disebut Pendapat Hukum Itu. Tulisan ini akan mencoba memaparkan mengenai sejarah dari Legal opinion, beserta perannya sebagai salah satu sumber hukum. Permasalahan yang diangkat adalah bagaimana sejarah dan perkembangan Legal Opinion serta bagaimana kedudukan legal opinion sebagai sumber hukum.

\section{Metode Penelitian}

Metode penelitian yang digunakan dalam penelitian ini adalah yuridis empiris, dengan meneliti bahan hukum primer yaitu legal opinion yang dibuat oleh seorang ahli hukum, bahan hukum sekunder yaitu buku, dan literatur terkait. Pendekatan yang digunakan adalah deskriptif analitis yaitu suatu cara analisis dengan menggambarkan objek yang diteliti. ${ }^{4}$ Teknik pengumpulan data yaitu studi kepustakaan yaitu mencari dan mengumpulkan data dari penelusuran bahan pustaka.

\section{Hasil Penelitian dan Pembahasan}

Sampai saat ini tidak ada definisi yang baku mengenai Legal Opinion di Indonesia. Tetapi apabila mengacu pada literatur yang telah ada sebelumnya dan yang telah berlaku secara internasional. Menurut Henry Campbell Black dalam Edisi Ketujuh Black's Law Dictionary (1999:1120), legal opinion diartikan sebagai : "A written document in which an attorney provides his or her understanding of the law as applied to assumed facts. The attorney may be a private attorney or attorney representing the state or other governmental entity". A party may entitled to rely on a legal opinion, depending on factors such as the identity of the parties to whom the opinion was addressed and the law governing these opinion, yang diartikan sebagai sekumpulan dokumen tertulis yang dijadikan padanan aplikasi bagi para pengacara atau pengertian pendapat hukum yang berkaitan dengan berbagai masalah hukum dari para pihak terkait sesuai dengan fakta-fakta nya. Seorang

\footnotetext{
4 Priyono, E. A. (2003). Bahan Kuliah Metodologi Penelitian. Semarang: Universitas Diponegoro, hlm. 23.
} 
pengacara bisa saja secara pribadi mewakili berbagai aspek peraturan institusi hukum yang mengatur tentang hal itu. Salah satu pihak berhak untuk meyakinkan pendapat hukum, tergantung dari faktor-faktor identitas para pihak terkait yang dibuat oleh seorang pengacara melalui pendapat hukum dan Undang-Undang yang mengaturnya.

Pengertian di atas memberikan penjelasan bahwa objek dari suatu legal opinion itu timbul dari adanya suatu fenomena atau polemik yang sangat dilematis yang disebabkan dari implikasi hukum itu sendiri, serta mempunyai akses yang sangat luas di dalam masyarakat, sehingga diperlukan suatu bentuk penjabaran yang konkret, aktual, dan faktual, untuk mengeliminasi topik persoalan yang menjadi pergunjingan tersebut di dalam masyarakat. ${ }^{5}$ Bahwa pada umumnya advokat mempergunakan hampir sebagian besar dari waktunya untuk memberikan nasehat hukum, baik secara lisan maupun tertulis dalam membantu para klien nya, baik untuk menghindari timbulnya sengketasengketa maupun untuk penyelesaian sengketa-sengketa. Salah satu bentuk dari nasehat hukum yang diberikan oleh seorang advokat bagi klien nya adalah melalui Pendapat Hukum (Legal Opinion).

Istilah Legal Opinion dalam bahasa latin disebut dengan Ius Opinion, dimana Ius artinya Hukum dan Opinion artinya pandangan atau pendapat. Legal opinion adalah istilah yang dikenal dalam sistem hukum Common Law (Anglo Saxon), sedangkan dalam sistem hukum Eropa Kontinental (Civil Law) dikenal dengan istilah Legal Critics yang dipelopori oleh aliran Kritikus Hukum. Dalam bahasa latin disebut sebagai ius opinion, artinya: Ius = hukum, dan Opinion = pandangan atau pendapat, jadi yang dimaksud dengan legal opinion adalah pandangan atau pendapat tentang masalah hukum yang dikaji baik secara parsial, imparsial, gradual, maupun krusial, khususnya menyangkut ketumpangtindihan pelaksanaan peraturan hukum. ${ }^{6}$ Jadi Legal opinion

\footnotetext{
${ }^{5}$ Hamzah, Halim. (2015). Cara Praktis Memahami dan Menyusun Legal Audit E Legal Opinion. Jakarta: Kencana, hlm. 201-202

${ }^{6}$ H.F, Abraham Amos. (2005). Legal Opinion Aktualisasi Teoritis E Empirisme. Jakarta: Raja Grafindo Persada, hlm. 4
} 
merupakan pendapat hukum yang berkaitan dengan masalah hukum dari para pihak terkait sesuai dengan fakta-fakta nya, yang dikaji baik secara parsial, imparsial, gradual, maupun krusial, khususnya menyangkut ketumpangtindihan pelaksanaan peraturan hukum.

Misalnya, seorang klien meminta pendapat hukum mengenai masalah hukum untuk kepentingan dirinya sendiri-bekas direktur PT meminta pendapat hukum apakah ia bisa digugat untuk perbuatannya selama ia menjabat sebagai direktur PT tersebut, padahal ia sekarang sudah melepaskan jabatannya, atau seorang investor perusahaan asing menanyakan tentang apa yang harus dilakukan apa ia ingin menanam modalnya pada bidang usaha tertentu di Indonesia. Sebagai langkah awal biasanya perusahaan asing itu ingin mengetahui segala ketentuan hukum yang mengatur kegiatan yang ia minati. Perusahaan yang berwawasan luas pasti ingin mengetahui segala hal yang berkaitan dengan investasi yang akan dilakukannya. Mengenai hal-hal yang berhubungan dengan masalah-masalah hukum biasanya perusahaan tersebut berusaha memperoleh pendapat hukum dari kantor hukum yang dianggapnya bonafid.

Pendapat Hukum ini memang dimaksudkan untuk memberikan keterangan kepada klien yang ingin mengetahui segala hal yang berkenaan dengan permasalahan yang dihadapinya, maka isinya juga harus dapat memenuhi harapan si klien tersebut, dengan demikian pendapat hukum sering tidak cukup hanya mengemukakan segi substantif dari segala peraturan yang dimintakan oleh klien, namun menjelaskan juga aspek struktural tentang lembaga-lembaga apa yang saja yang memiliki kaitan dengan permasalahan klien bersangkutan. Sering juga mengikat pada budaya hukum yang meliputi sistem nilai yang berpengaruh terhadap sikap dan tindakan warga masyarakat yang memiliki sangkut paut dengan pertanyaan klien. Pendapat hukum tidak hanya mengemukakan apa yang seharusnya akan tetapi juga apa yang nyatanya 
ada. ${ }^{7}$ Legal opinion bertujuan untuk menjabarkan suatu kontekstual hukum baik implisit maupun eksplisit, jika terdapat berbagai kontradiksi yuridis yang berakibat protes masyarakat terhadap penerapan suatu aturan hukum, atau dengan kata lain terdapat penyimpangan norma-norma kultural yang berlaku dalam suatu masyarakat, dan jika hukum itu diterapkan maka akan timbul dampak yang luas yang dapat mempengaruhi stabilitas keamanan negara dan sosial politik 8

\subsection{Sejarah Legal Opinion}

Legal Opinion adalah istilah yang dikenal dalam sistem hukum Common Law (Anglo Saxon), sedangkan dalam sistem hukum Civil Law (Eropa Continental) dikenal sebagai Legal Critics yang dipelopori oleh aliran kritikus hukum. ${ }^{9}$ Legal Opinion mulai dikenal dalam praktek hukum penasehat hukum di Indonesia yang terlibat dalam transaksi komersial internasional dan berhadapan dengan penasehat hukum asing. Penasehat hukum asing ini mensyaratkan sebagai persyaratan awal (a condition precedent) dari berlakunya perjanjian Legal Opinion harus dipersiapkan dan dikeluarkan oleh penasehat hukum Indonesia bagi berlakunya suatu perjanjian. ${ }^{10}$

Seorang penasehat hukum tidaklah boleh gegabah dalam memberikan Legal Opinion nya, apalagi bila berkaitan dengan dimensi Internasional. Agar seorang penasehat hukum dapat memberikan Legal Opinion yang baik, maka ia haruslah mengerti dan memahami mengenai masalah hukum yang ada dan mengapa hal tersebut bisa terjadi. Praktek keharusan membuat dan menyampaikan pada yang berkepentingan pada mulanya merupakan praktek hukum di Amerika Serikat dalam bermacam macam transaksi komersial seperti peleburan dan penggabungan perjanjian pinjaman uang dari bank dan penjualan

\footnotetext{
7 Victor, Purba, (et.al). (1993). Penulisan Hukum. Jakarta: Konsorsium Ilmu Hukum, hlm. 32-33

8 Syahrul Sitorus. (2018). "Pendapat Hukum (Legal Opinion) dan Uji Kepatutan Dari Segi Hukum (Legal Due Diligence)". Jurnal Hikmah. 15(2). p. 167

${ }^{9}$ Hamzah Halim. Op. cit, hlm. 203

10 D Didik Suraputra. (2005). “Pendapat Hukum Dalam Transaksi Komersial”. Jurnal Hukum dan Pembangunan, 35(2):135- 143
} 
surat surat berharga. Para Penasehat Hukum Amerika begitu juga dengan klien klien mereka bahwa selain dari akta jual beli tanah (conveyancing instruments), perangkat Pendapat Hukum adalah dokumen hukum yang sangat pentingdikeluarkan sebagai persyaratan bagi berlakunya suatu perjanjian. Dapat dimengerti kalau Penasehat Hukum dari Negara lain diluar Amerika Serikat, pada awalnya enggan mengeluarkan Pendapat Hukum, karena praktek maupun kebudayaan hukumnya berbeda dari hukum Amerika Serikat. ${ }^{11}$ Termasuk didalamnya adalah Indonesia yang kebudayaannya bertentangan dengan Amerika Serikat tentunya tidak serta merta mengikuti kebudayaan yang berasal dari Amerika Serikat itu sendiri.

Menurut pendapat Penasehat Hukum Perancis: "It is inconsistent with the dignity of our profession and contrary to our ethics to render a legalopinion". Sebagian besar dari praktek Penasehat Hukum Perancis, tidak menaruh perhatian dan tidak merasakan ada kegunaannya untuk mengeluarkan Penadapat Hukum bagi masalah hukum domestik. Hanya sebagian kecil saja dari Penasehat Hukum Perancis yang terlibat dalam transaksi komersial transnasional dan mengeluarkan pendapat hukum. ${ }^{12}$ Artinya di Perancis pun sama sekali tidak menyambut baik tentang kebudayaan membuat Legal Opinion karena sebagian besar penasehat hukum di Perancis merasa Legal Opinion tidak diperlukan dalam permasalahan hukum.

Pada mulanya Penasehat Hukum Inggris yang terlibat dalam transaksi internasional pinjaman uang dari bank Amerika juga berkeberatan mengeluarkan Legal Opinion berdasarkan dua alasan. Pertama-tama, memberikan pendapat hukum pada kliennya sendiri mengenai keabsahan dokumen-dokumen yang dipersiapkan untuk transaksi, tidak lain hanya menyimpulkan kembali hasil kerja, yang seharusnya dilakukan dalam rangka hubungan kerja antara klien dan Penasehat Hukumnya. Dalam keadaan tersebut maka sebenarnya pengeluaran pendapat hukum adalah tidak perlu dan tidak

11 Ibid, hlm. 144

12 Ibid, hlm. 146. 
memberikan tambahan keuntungan maupun kemungkinan dikemudian hari menderita kerugian. Kedua memberi pendapat hukum pada pihak lain bukan klien, maka para penasehat hukum akan dihadapkan pada benturan kepentingan dimana penasehat hukum harus memberikan informasi yang konfidensial pada pihak lain yang seharusnya tidak diberikan. Dalam konteks tersebut maka penyampaian Pendapat Hukum adalah tidak sehat dan juga membawa kemungkinan tambahan kerugian yang potensial. Keberatan pertama telah ditinggalkan, karena dari pihak Bank tetap menghendaki dikeluarkannya Pendapat Hukum sebagai syarat utama dilaksanakanya pada perjanjian pinjaman uang. Keberatan kedua dapat diatasi dengan izin resmi dari klien pada Penasehat Hukumnya agar semua informasi yang diperlukan disampaikan pada pihak-pihak yang berkepentingan. ${ }^{13}$ Kemudian praktek mengeluarkan Pendapat Hukum pun yang tadinya merupakan praktek transaksi komersial domestik Amerika Serikat, menyebar ke sebagian besar negara-negara lain, tanpa harus ada keterlibatan Penasehat Hukum Amerika Serikat lagi.

Hal yang terjadi pada para penasihat hukum di Inggris ini pada dasarnya sama seperti yang dialami oleh para penasehat hukum di Indonesia. Karena berdasarkan Kode Etik Advokat Pasal 4 huruf h dinyatakan bahwa "Advokat wajib memegang rahasia jabatan tentang hal-hal yang diberitahukan oleh klien secara kepercayaan dan wajib tetap menjaga rahasia itu setelah berakhirnya hubungan antara Advokat dengan klien itu". Ketentuan ini juga berkaitan dengan Pasal 19 Undang-Undang Nomor 18 Tahun 2003 tentang Advokat mengenai kewajiban seorang Advokat. ${ }^{14}$

Pasal 19

(1) Advokat wajib merahasiakan segala sesuatu yang diketahui atau diperoleh dari klien nya karena hubungan profesinya, kecuali ditentukan lain oleh UndangUndang.

\footnotetext{
${ }^{13} \mathrm{Ibid}, \mathrm{hlm} .144-145$

${ }^{14}$ Maharani Roya Ananta. (2014). “Implementasi Kewajiban Advokat Dalam Menjaga Rahasia Klien”. Jurnal Fakultas Hukum Universitas Brawijaya Malang. 14 (1), hlm. 4.
} 
(2) Advokat berhak atas kerahasiaan hubungannya dengan klien, termasuk perlindungan atas berkas dan dokumen nya terhadap penyitaan atau pemeriksaan dan perlindungan terhadap penyadapan atas komunikasi elektronik Advokat.

\section{Mekanisme Penyusunan Legal Opinion}

Pemahaman tentang hukum tidak terbatas hanya pada peraturan perundang-undangan saja, tetapi juga bersumber pada keputusan-keputusan pengadilan dan pendapat-pendapat para praktisi hukum senior. Isi pendapat hukum tidak hanya berkisar pada bunyi peraturan perundang-undangan saya tetapi juga menyangkut bagaimana pelaksanaan ketentuan perundangundangan itu dalam praktik sehari-hari. In konsistensi antara peraturan perundang-undangan yang satu dengan peraturan perundang-undangan yang lain, baik secara vertical maupun horizontal, hal inilah yang menjadi tantangan penyusunan suatu legal opinion. Hal-hal yang harus diperhatikan dalam penyusunan Pendapat Hukum, yaitu;

a. akurat, "check and recheck" harus dilakukan untuk menghindarkan kesalahan fakta-fakta, pendapat-pendapat, angka-angka, kutipankutipan dan kepustakaan.

b. singkat, hal-hal yang tidak relevan tak usah dituliskan,

c. jelas, "ambiguity" harus dihindarkan dalam penulisan Pendapat Hukum,

d. Perurutan, pemilihan dan pengaturan bahan harus cukup sistematis. ${ }^{15}$

Pada dasarnya Legal Opinion merupakan bagian dari Legal Memoranda bersama dengan nasehat hukum (Legal Advice) dan pemecahan masalah hukum (Problem solving). Oleh karena itu format penyusunannya sama dengan Legal

\footnotetext{
15 Erman Rajagukguk, "Pentingnya Pengetahuan dan Kemampuan Menyusun “Pendapat Hukum” (Legal Opinion) dan Kemampuan Ilmiah (academic writing) bagiSarjana Hukum", Makalah disampaikan di Jakarta, 1993, hal. 100-101
} 
Memoranda. ${ }^{16}$ Adapun dalam penyusunan legal opinion terdapat lima aturan dasar (five golden rules) yang harus diikuti, yang terdiri dari: ${ }^{17}$

1. Issues atau Pokok Permasalahan

2. Facts atau Fakta-Fakta

3. Rules atau Aturan Hukum yang dapat atau mungkin dapat diterapkan dalam kasus tersebut.

4. Application atau Penerapan Hukum

5. Conclusion atau Kesimpulan.

\section{Prinsip-Prinsip dalam Pembuatan Legal Opinion}

Prinsip yang harus dipegang dalam menyusun Legal Opinion, adalah sebagai berikut:

a. Legal Opinion dibuat dengan mendasarkan pada hukum Indonesia.

Advokat yang berpraktek dalam wilayah Republik Indonesia dimana hukum yang dikuasai adalah hukum Indonesia, tidak berkompeten untuk menyampaikan pendapat hukum yang didasarkan pada hukum selain hukum Indonesia.

b. Legal Opinion disampaikan secara lugas, jelas dan tegas dengan tata bahasa yang benar dan sistematis.

Legal Opinion disampaikan secara lugas, jelas dan tegas, artinya legal opinion tersebut harus mudah dipahami oleh klien atau bagi pihak yang membacanya. Karena disampaikan dengan bahasa yang baik dan sistematis serta tegas maka Legal Opinion tersebut tidak menimbulkan tafsiran berganda (bias) dan diharapkan melalui Legal Opinion tersebut tercipta lah suatu kepastian hukum.

c. Legal Opinion tidak memberikan jaminan terjadinya suatu keadaan

\footnotetext{
16 Fakultas Hukum Universitas Diponegoro. (2016). Buku Panduan Penulisan Hukum (Skripsi). Semarang: Universitas Diponegoro, p. 1.

17 Yuliati, Teknik Penyusunan Legal Memorandum, Makalah disampaikan dalam Acara Pelatihan Penyusunan Legal Opinion oleh Labolatorium Hukum Fakultas Hukum Universitas Brawijaya, 27-28 Oktober 2004
} 
Dalam Legal opinion, advokat tidak boleh memberikan jaminan atau kepastian akan kondisi suatu penyelesaian persoalan dalam praktek. Hal ini sesuai pula dengan ketentuan yang terdapat dalam Pasal 4 butir c Kode Etik Advokat yang berbunyi: "Advokat tidak dibenarkan menjamin kepada klien nya bahwa perkara yang ditanganinya akan menang". Dilihat dari isi Kode Etik Advokat tersebut dapat disimpulkan bahwa advokat di dalam Legal Opinion nya tidak dapat memberikan jaminan kepada klien bahwa perkara yang ditanganinya akan menang.

d. Legal Opinion harus diberikan secara jujur dan lengkap

Jujur, artinya Legal Opinion harus disampaikan kepada klien sebagaimana adanya, tidak dibuat-buat dan tidak semata-mata memberikan pendapat hanya untuk mengakomodir keinginan klien. Jika berdasarkan ketentuan hukum yang berlaku keinginan klien tidak dapat terpenuhi, maka hal tersebut harus dikemukakan dengan jelas dalam Legal Opinion, tanpa ada yang ditutupi.

Penjelasan dalam Legal Opinion harus diberikan dengan selengkapnya. Dalam Legal Opinion advokat tidak memberikan pendapat yang mengharuskan klien untuk melakukan tindakan tertentu. Legal Opinion hanya bersifat memberikan pendapat mengenai tindakan-tindakan apa yang harus dilakukan oleh klien tetapi klien sendiri yang akan memutuskan apakah akan melakukan tindakan tersebut atau tidak. Oleh karena itu Legal Opinion harus memberikan penjelasan yang selengkapnya, sehingga klien memiliki bahan pertimbangan yang cukup untuk mengambil suatu keputusan.

e. Legal Opinion tidak mengikat bagi advokat dan bagi klien Advokat bertanggung jawab atas isi dan juga bertanggung jawab atas kebenaran dari Legal Opinion yang dibuatnya., tetapi advokat tidak dapat dimintakan pertanggungjawaban atas kerugian yang timbul akibat klien mengambil tindakan berdasarkan Legal Opinion tersebut. Legal Opinion yang dibuat oleh advokat yang ditunjuk tersebut tidak mengikat klien atau pihak-pihak yang meminta Legal Opinion untuk 
melaksanakan sebagian atau seluruh isi dari Legal Opinion. Keputusan untuk mengambil atau tidak mengambil tindakan berdasarkan Legal Opinion, sepenuhnya tergantung dari klien yang bersangkutan dan menjadi tanggung jawab dari pengambil keputusan.

\section{Fungsi Legal Opinion}

Sesuai dengan pengertiannya yang telah diulas sebelumnya maka Legal Opinion biasanya digunakan untuk menjawab pertanyaan-pertanyaan klien tentang suatu permasalahan hukum tertentu. Legal Opinion ini memang dimaksudkan untuk memberikan keterangan kepada klien yang ingin mengetahui segala hal yang berkenaan dengan permasalahan yang dihadapinya, maka isinya juga harus dapat memenuhi harapan si klien tersebut. ${ }^{18}$ Berdasarkan pernyataan di atas dapat ditarik kesimpulan bahwa fungsi dari Legal Opinion adalah untuk memberikan pendapat hukum atas suatu persoalan hukum agar didapat suatu keputusan atau tindakan yang tepat atas persoalan hukum tersebut.

Pada tataran praktis, seorang hakim tidak boleh hanya menjadi corong Undang-Undang, namun ia juga harus melakukan penemuan hukum yang dituangkan dalam setiap putusannya, dalam proses penemuan hukum tersebut hakim harus berpegang pada prinsip bahwa hukum adalah untuk manusia bukan manusia untuk Hukum, sehingga hakim harus mengedepankan nilai keadilan alam masyarakat dan menyesuaikan dengan perubahan masyarakat. ${ }^{19}$ Artinya seorang hakim juga memberikan pendapat hukum dalam setiap putusannya, sehingga legal opinion juga berfungsi sebagai penemuan hukum oleh hakim.

\footnotetext{
18 Paulus Hadisuprapto, Pendapat Hukum (Legal Opinion), hlm 3-4 (Makalah disajikan sebagai Materi Kuliah “Legal Opinion" pada Pendidikan Khusus Profesi Advokat, Fakultas Hukum Universitas Diponegoro, Semarang, 11 Maret 2007)

19 Siti Malikhatun Badriyah. (2011). "Penemuan Hukum (Rechtsvinding) dan Penciptaan Hukum (Rechtsschepping) Oleh Hakim Untuk Mewujudkan Keadilan”. Masalah-Masalah Hukum. 40 (3), hlm. 392
} 
Pendapat Hukum bagi dunia usaha mempunyai dua fungsi yaitu, fungsi yang pertama pendapat tanpa syarat dan menguntungkan (an unquailed favorable opinion), artinya pendapat hukum tersebut menjadi pertimbangan pengusaha agar mengambil tindakan yang menguntungkan bagi bisnisnya. Fungsi yang kedua daIam hal Penasehat Hukum tidak dapat memberikan Pendapat Hukum tanpa syarat dan tidak menguntungkan, maka pendapat ini dapat merupakan suatu peringatan bagi pengusaha, mengenai adanya kemungkinan resiko yang harus menjadi pertimbangan dalam mengambil keputusan komersial. ${ }^{20}$

\subsection{Kedudukan Legal Opinion sebagai Sumber Hukum}

Pendapat hukum atau Legal Opinion atau bila ditinjau dari sumber-sumber hukum masuk ke dalam Doktrin. Sumber hukum pada hakikatnya adalah tempat kita dapat menemukan atau menggali hukumnya ${ }^{21}$ Undang-Undang perjanjian internasional dan yurisprudensi adalah sumber hukum. Tidak mustahil ketiga sumber hukum itu tidak bisa langsung diaplikasikan terhadap permasalahan konkret nya sehingga dibutuhkan pendapat hukum dari sarjana hukum atau pakar hukum. Pendapat para sarjana hukum yang merupakan doktrin adalah sumber hukum, tempat hakim dapat menemukan hukumnya. ${ }^{22}$ Sumber hukum dalam pengertiannya adalah asalnya hukum yang berupa keputusan penguasa yang berwenang untuk memberikan keputusan tersebut Artinya, keputusan itu haruslah dari penguasa yang berwenang untuk itu. ${ }^{23}$ Selain itu pengertian sumber hukum dalam pengertiannya sebagai hal-hal yang dapat atau seyogianya mempengaruhi kepada penguasa di dalam menentukan hukumnya. Misalnya keyakinan akan hukumnya, rasa keadilan, perasaan akan hukumnya entah dari penguasa atau rakyatnya, dan juga teori-teori, pendapatpendapat dan ajaran-ajaran dari ilmu pengetahuan hukum. ${ }^{24}$

\footnotetext{
20 D. Sidik Suraputra. (2005). "Pendapat Hukum Dalam Transaksi Komersial”. Jurnal Hukum dan Pembangunan. 35 (2), hlm. 146

${ }^{21}$ Sudikno Mertokusumo. Op Cit, hlm. 107

22Sudikno Mertokusumo. Op Cit, hlm. 151

23 Theresia Ngutra. (2016). “Hukum Dan Sumber-Sumber Hukum”. Jurnal Supremasi. 11 (2), . hlm. 194

24 Ibid, hlm. 194-195
} 
Doktrin merupakan pendapat dari para pakar yang dirangkum untuk dijadikan suatu acuan baru bagi perkembangan hukum. Sebagai contoh seperti pada abad sembilan belas dengan teori hukum kontrak klasiknya sebagai reaksi dan kritik terhadap tradisi abad pertengahan mengenai substantive justice, kritik yang dikemukakan oleh para sarjana dan ahli hukum ini merupakan suatu pendapat hukum atau Legal Opinion. Selanjutnya pendapat Friedman tentang kebebasan berkontrak masih dianggap aspek yang essensial dari kebebasan individu. Pendapat ini merupakan suatu Legal Opinion atas suatu permasalahan yang timbul karena pergeseran aturan mengenai kebebasan berkontrak.

Akan tetapi agar suatu Legal Opinion ini mempunyai kekuatan hukum mengikat, pendapat hukum ini harus memenuhi syarat tertentu yaitu pendapat hukum yang telah menjadi putusan hakim, dengan demikian Legal Opinion berperan penting dalam pembangunan hukum bukan hanya dalam aspek perjanjian melainkan dapat lebih luas daripada itu. Legal Opinion bisa juga dijadikan suatu kritikan terhadap suatu kebijakan yang tentunya dapat menjadi suatu masukan yang positif demi mendorong perubahan kebijakan ke arah yang lebih baik.

\section{Kesimpulan}

Berdasarkan pemaparan yang telah dibahas pada bab sebelumnya, maka hasil dari pembahasan dapat disimpulkan sebagai berikut:

1. Bahwa Legal Opinion sangat diperlukan sebagai bahan pertimbangan bagi para pihak yang berkepentingan dan sedang mengalami permasalahan hukum agar dapat membuat dan mengambil suatu keputusan atau tindakan yang tepat berkenaan dengan masalah yang dihadapi.

2. Legal Opinion memiliki kedudukan penting yaitu sebagai dasar pemikiran yang diungkapkan oleh para sarjana dan ahli hukum dalam hal perkembangan hukum. Pendapat hukum atau Legal Opinion dari para pakar tersebut dirangkum untuk dijadikan suatu acuan baru bagi 
perkembangan hukum, dapat juga berupa kritikan terhadap suatu kebijakan dengan maksud memberikan saran atau masukan, agar memiliki kekuatan hukum tetap, pendapat hukum ini harus termuat dalam suatu putusan hakim. Artinya Legal opinion merupakan sumber hukum yang bisa dikategorikan sebagai doktrin, dan akan mempunyai kekuatan hukum mengikat jika sudah menjadi putusan hakim. 


\section{Daftar Pustaka}

Buku

Abraham, H.F Amos. (2005). Legal Opinion Aktualisasi Teoritis E Empirisme. Jakarta: Rajagrafindo Persada

Fakultas Hukum Universitas Diponegoro. (2016). Buku Panduan Penulisan Hukum (Skripsi). Semarang: Universitas Diponegoro

Halim, Hamzah. (2015). Cara Praktis Memahami dan Menyusun Legal Audit E Legal Opinion. Jakarta: Kencana

Mertokusumo, Sudikno. (2008). Mengenal hukum Suatu Pengantar. Yogyakarta: Liberty

Purba, Victor, (et.al). (1993). Penulisan Hukum. Jakarta: Konsorsium Ilmu Hukum Rahardjo, Satjipto. (2014). Ilmu Hukum. Semarang: Citra Aditya Bakti

Artikel Jurnal

Badriyah, Siti Malikhatun. (2011). "Penemuan Hukum (Rechtsvinding) dan Penciptaan Hukum (Rechtsschepping) Oleh Hakim Untuk Mewujudkan Keadilan". Masalah-Masalah Hukum. 40 (3), hlm. 384-392

Didik, D Suraputra. (2005). "Pendapat Hukum Dalam Transaksi Komersial". Jurnal Hukum dan Pembangunan, 35 (2), hlm. 140-153

Ngutra, Theresia. (2016). "Hukum dan Sumber-Sumber Hukum". Jurnal Supremasi. 11(2), hlm. 181-194

Roya, Maharani Ananta. (2014). “Implementasi Kewajiban Advokat Dalam Menjaga Rahasia Klien". Jurnal Fakultas Hukum Universitas Brawijaya Malang, 3 (3), hlm. 23-43

Sitorus, Syahrul. (2018). “Pendapat Hukum (Legal Opinion) Dan Uji Kepatutan Dari Segi Hukum (Legal Due Diligence)”. Jurnal Hikmah. 15(2), hlm. 166-178

Suraputra, D. Sidik. (2005). “Pendapat Hukum Dalam Transaksi Komersial”. Jurnal Hukum dan Pembangunan. 35 (2), hlm. 143-166 
Makalah dan Bahan Ajar

Rajagukguk, Erman. (1993). Pentingnya Pengetahuan dan Kemampuan Menyusun "Pendapat Hukum" (Legal Opinion) dan Kemampuan Ilmiah (academic writing) bagi Sarjana Hukum. Makalah disampaikan di Jakarta, hlm. 100-123

Paulus Hadisuprapto. (2007). Pendapat Hukum (Legal Opinion), hlm 3-4 Makalah disajikan sebagai Materi Kuliah “Legal Opinion” pada Pendidikan Khusus Profesi Advokat. Semarang: Fakultas Hukum Universitas Diponegoro

Priyono, E. A. (2003). Bahan Kuliah Metodologi Penelitian. Semarang: Universitas Diponegoro

Yuliati. (2004). Teknik Penyusunan Legal Memorandum, Makalah disampaikan dalam Acara Pelatihan Penyusunan Legal Opinion oleh Laboratorium Hukum Fakultas Hukum Universitas Brawijaya. 